\title{
THE CENOZOIC VERTEBRATE FOSSILS FROM THE \\ NEPAL HIMALAYA: A REVIEW
}

\author{
K.N. Paudayal
}

\section{ABSTRACT}

The last four decades have been fruitful for recording the Cenozoic vertebrate fossils in the Nepal Himalaya.This information is very important to understand the evolution of vertebrate fauna as well as the climate in which they were living during and after the collision of the Indian subcontinent to Eurasian continent. This paper gives a review of the landmark contribution which has been made by different authors on this aspect.

Key words: vertebrate fossils, Cenozoic, Nepal Himalaya

\section{INTRODUCTION}

The collision of the Indian subcontinent to the Eurasian continent in early Cenozoic was an important event because it was responsible for the formation of the great Himalayan ranges and development of the monsoonal climatic system in the southern Asia. The continuous movement of the Indian Plate underneath the Tibetan Plate resulted in the long-term crustal deformation, exhumation and the development of the different EW trending thrust faults all across the Himalayas. These thrusts are supposed to be formed to release excessive stress which caused major seismic events during the orogeny. On the basis of EW trending faults, the geology of the Nepal Himalaya is separated into five different tectonic units. From south to north, these are: (1) The Indo-Gangetic Plain, (2) The Sub-Himalaya or Siwalik also known as the Churia range, (3) The Lesser Himalaya, also known as Lower Himalaya. (4) The Higher Himalaya, also known as the Greater Himalaya, and, (5) The Tethys Himalaya or Tibetan Sedimentary series (Figure 1). The Himalayan Frontal Thrust (HFT) separates the Indo-Gangetic Plain in the south and the Siwalik to the north. The Main Boundary Thrust (MBT) separates the Siwalik and the Lesser Himalaya. Similarly the Main Central Thrust separates the Lesser Himalaya and the Higher Himalaya. The Higher Himalaya is separated with the Tethys Himalaya by normal fault system named as STDS (South Tibet Detachment System). So this study intends to summarize the vertebrate fossil-records from different tectonic units in Nepal.

\section{VERTEBRATE FOSSIL RECORDS}

\section{The Indo-Gangetic Plain}

The Indo-Gangetic Plain lies at the southern margin of the Siwalik mountain range. Tectonically, it is separated from the Siwalik by a fault called Himalayan Frontal Thrust (HFT). The Indo-Gangetic Plain is composed of Quaternary alluvial sediments that have been deposited by the major rivers originating from the Higher, Lesser and Sub-Himalayas. The alluvial deposits of the Indo-Gangetic Plain are rich in Pleistocene-Holocene vertebrate fossils as well as many prehistoric remains belonging to Palaeolithic-Mesolithic human culture. Middle Pleis- 
tocene cattle Bos cf. namadicus was reported from southern part of the Himalayan Frontal Thrust in Chabeni-Satpati area near Trivenighat in Nawalparasi District (Corvinus 1996). She also reported Early Pleistocene to Holocene handaxes, handchopper, scrapper, corescrapper, flintflakes from Gadari, Gidhiniya, Shitalpur, Tui (Dang-Deukhuri Valley) and Patu (Rato Khola, Mahottari) areas (fig.1).The Stone Age culture of Nepal is well documented from the Indo-Gangetic sediments (Corvinus 1985, 1987, 1989, 1995).

\section{The Siwalik}

The Siwalik mountain range, also known as the Sub-Himalaya and/or Churia Range in Nepal is distributed throughout the country in between Himalayan Frontal Thrust (HFT) in the south and the Main Boundary Thrust (MBT) to the north. The sediments, which constitute the Siwalik mountain belt, are massively derived from the weathering mantle of the Lesser and the Higher Himalayan rocks that have been eroded by the antecedent rivers throughout the mountain uplift process. The geological age of these sediments ranges from Middle Miocene to Lower Pleistocene and the total thickness reach up to 5000 to $6000 \mathrm{~m}$ in some sections. The lower part of the Siwalik is composed of variegated mudstones intercalated with fine to medium grained sandstones. The proportion of sandstone is lesser than mudstones. The middle part of Siwalik is composed of medium to coarse grained sandstone with few mudstone beds. The sandstones are thick to very thick bedded rich with quartz, feldspar and mica giving 'salt and pepper' texture. The upper part of the Siwalik is composed of conglomerates, sandstone and few mudstone beds. The Siwalik Group of sediments yielded many vertebrate remains from the different part of the country (West et al. 1978, Munthe et al. 1983, West and Munthe 1983, West et al. 1983, West 1984, Corvinus 1988a, 1988b, 1990, 1993, 1994, West et al.1991, Nanda and Corvinus 1993, Corvinus and Nanda 1994, Sah et al. 1994,West 1996, Kotlia and Mathur 1997, Nanda and Corvinus 2000, Corvinus and Rimal 2001).

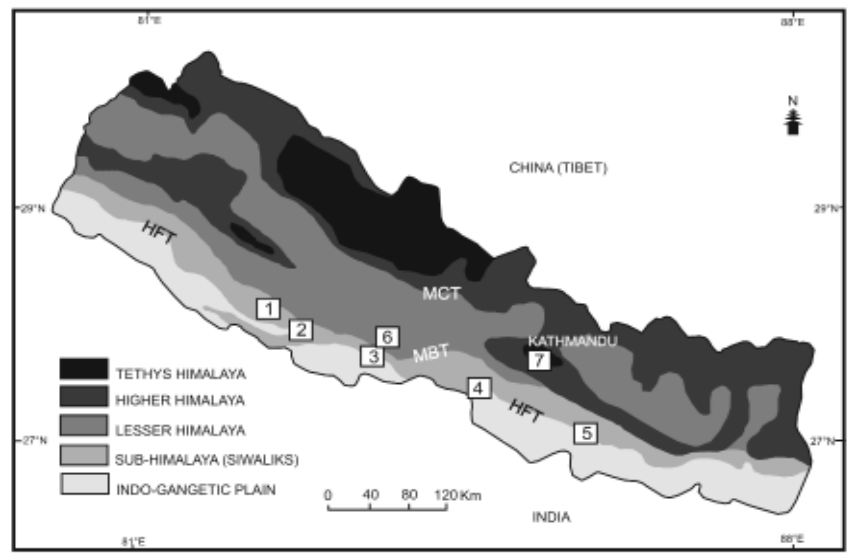

Figure 1.Cenozoic vertebrate fossil localities in Nepal (1.Tui Khola, 2. Surai Khola, 3. Tinau Khola, 4. Dudhaura Khola, 5. Rato Khola, 6. Tansen, and 7. Kathmandu Valley). HFT (Himalayan Frontal Thrust), MBT (Main Boundary Thrust), MCT (Main Central Thrust). 
by West et al. (1978). Their earlier investigation in eastern Siwalik was able to report a few molluscan fossils (West et al.1975). In total, 52 vertebrate specimens were recorded from 17 different localities in Tui Valley and systematically described tolower taxonomic level (West et al. 1978). After many stages of fieldworks in Tui Khola, Babai River, Rapti River, Balim Khola, Kalapani in Dang-Deukhuri Valley and Tinau Khola they concluded their findings with 600 vertebrate fossil specimens from 54 sites (West et al. 1991). The most significant finding was a primate tooth of Sivapithecus punjabicus discovered from the Lower Siwalik in the Tinau Khola section (fig. 2) (Munthe et al. 1983). The palaeomagnetic date of the tooth horizon is 9.0-9.5 Ma. This finding is a mileage to understand the distribution of Late Miocene hominoids in the southern Asia. On the basis of the faunal remains they correlated their findings with the Chinji and Nagri Formations of Potwar Basin, Pakistan and established the time-frame of the Siwalik deposits in Nepal.The overall findings of West et al. (1978), Munthe et al. (1983), West et al. (1991) and West (1996) are listed in table 1.

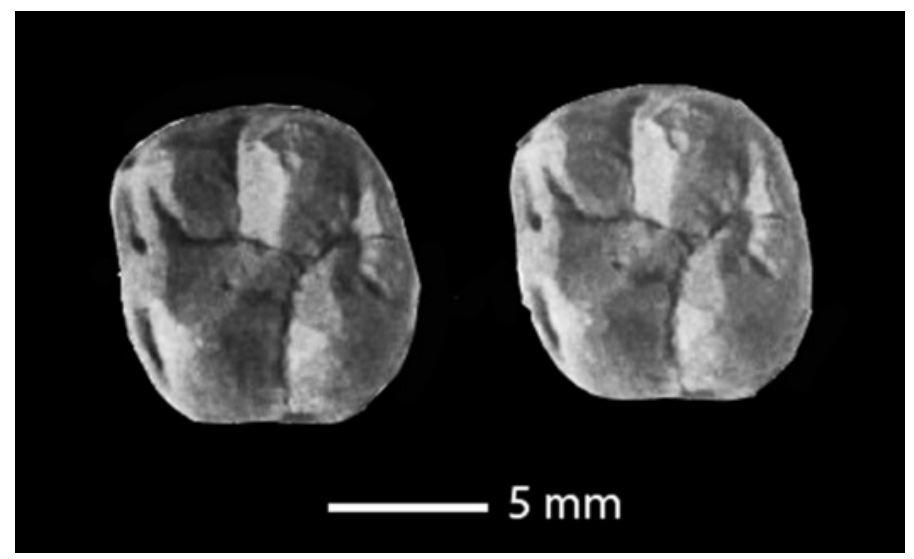

\section{Figure 2.The left upper molar of Sivapithecus punjabicus from the Lower Siwalik in the Tinau Khola section, west Nepal (Photograph from Munthe et al. 1983).}

Corvinus (1988a, 1988b, 1990, 1993, 1994), Nanda and Corvinus (1993), Corvinus and Nanda (1994), Nanda and Corvinus (2000), Corvinus and Rimal (2001) studied the fossil remains of the Siwalik Group along Surai Khola (west Nepal) and Rato Khola (east Nepal) sections for about two decades. Corvinus heavily collected the vertebrate fossils from the Surai Khola area along with stratigraphical documentation. On the basis of lithological character she divided the stratigraphy of the Siwalik Group along the Surai Khola section into five units namely the Bankas Formation, Chor Khola Formation, Surai Khola Formation, Dobatta Formation and Dhan Khola Formation. Palaeomagnetic dating of the Surai Khola sequence indicated a time scale from 13 to $1 \mathrm{Ma}$ (Appel et al. 1991, Appel and Roesler 1994). The vertebrate remains from the Surai Khola and Rato Khola sections are listed in table 2. The micro remains of the vertebrate skeleton are abundant in the Siwalik. Cyprinid teeth (4-types), scales (2-types), and spines (2-types) along with Crocodylus teeth (2-types) from the Upper Siwalik in the Surai Khola section were reported by Kotlia and Mathur (1997). In their study, Sah et al. (1994) found 
a limb bone (possibly Bovid) from the Churia Mai Formation (Upper Siwalik) in the HetaudaAmlekhganj section. After the collision of the India and Eurasian Plates in Eocene the Himalaya became an ecologic barrier between south and central Asia, the rising range may have had an effect on foothills climate. The faunal patterns indicate a generally drier climate westward (West et al.1991).

Table 1. Vertebrate fossils from Siwalik from the Tui Khola, Balim Khola, Kalapani, Rapti River (Dang-Deukhuri) and the Tinau Khola (Butwal) areas (West et al. 1991).

\begin{tabular}{|c|c|c|c|}
\hline CLASS & ORDER & FAMILY & GENERA/SPECIES \\
\hline \multirow{4}{*}{ OSTEICHTHYS } & Cypriniformes & Cyprinidae & indet. \\
\hline & Channiformes & Channidae & Channa sp. \\
\hline & Siluriformes & Clariidae & indet. \\
\hline & indet. & indet. & indet. \\
\hline \multirow{10}{*}{ REPTILIA } & \multirow{3}{*}{ Crocodilia } & \multirow{2}{*}{ Crocodylidae } & Crocodylus sp. \\
\hline & & & cf. Tomistoma sp. \\
\hline & & Gavialidae & Gavialis sp. \\
\hline & Squamata & Acrochordidae & Acrochordus dehmi \\
\hline & \multirow{6}{*}{ Testudines } & \multirow{3}{*}{ Emydidae } & Batagur sp. \\
\hline & & & Cuora or Chinemys sp. \\
\hline & & & Kachuga sp. \\
\hline & & Testudinidae & Geochelone sp. \\
\hline & & \multirow{2}{*}{ Trionychidae } & Lissemys puntata \\
\hline & & & Chitra cf. C. indica \\
\hline
\end{tabular}


MAMMALIA

\begin{tabular}{|c|c|c|}
\hline \multirow{9}{*}{ Artiodactyla } & $\begin{array}{l}\text { Anthracotheri- } \\
\text { idae }\end{array}$ & Hemimeryx pusillus \\
\hline & \multirow{4}{*}{ Bovidae } & Sivoreas eremita \\
\hline & & Protragocerus gluten \\
\hline & & Pachyportax sp. \\
\hline & & indet. \\
\hline & Giraffidae & Giraffokeryx punjabiensis \\
\hline & Suidae & Conohyus sindiensis \\
\hline & \multirow{2}{*}{ Tragulidae } & Docrabune sp. \\
\hline & & Dorcatherium \\
\hline Carnivora & $\begin{array}{l}\text { Amphicyoni- } \\
\text { dae }\end{array}$ & Amphicyon palaeindicus \\
\hline Creodonta & $\begin{array}{l}\text { Hyaenodon- } \\
\text { tidae }\end{array}$ & indet. \\
\hline \multirow{2}{*}{ Perissodactyla } & Rhinocerotidae & $\begin{array}{l}\text { Brachypotherium peri- } \\
\text { mense }\end{array}$ \\
\hline & Equidae & Hipparion sp. \\
\hline \multirow{2}{*}{ Proboscidea } & Deinotheriidae & $\begin{array}{l}\text { Deinotherium penta- } \\
\text { potamidae }\end{array}$ \\
\hline & $\begin{array}{l}\text { Gomphotheri- } \\
\text { idae }\end{array}$ & indet. \\
\hline Rodentia & Rhizomyidae & indet. \\
\hline Primates & Pongidae & Sivapithecus punjabicus \\
\hline
\end{tabular}


Table 2. Vertebrate fossils from the Siwalik in the Surai Khola (Dang) and the Rato Khola (Mahottari) areas (Corvinus and Rimal 2001).

\begin{tabular}{|c|c|c|c|}
\hline CLASS & ORDER & FAMILY & GENERA/SPECIES \\
\hline \multirow{7}{*}{ REPTILIA } & \multirow{3}{*}{ Crocodilia } & Crocodylidae & Crocodylus palustris \\
\hline & & \multirow{2}{*}{ Gavialidae } & Gavialis cf. G. gangeticus \\
\hline & & & Rhamphosuchus crassidens \\
\hline & \multirow{4}{*}{ Testudines } & Testudinidae & Colossochelys atlas \\
\hline & & \multirow{2}{*}{ Trionychidae } & Aspideretes sp. \\
\hline & & & Lissemys puntata \\
\hline & & Emydidae & Batagurini sp. \\
\hline \multirow{13}{*}{ MAMMALIA } & \multirow{8}{*}{ Artiodactyla } & Anthracotheriidae & Merycopotamus cf. M. dissimilis \\
\hline & & \multirow{3}{*}{ Bovidae } & Proamphibos cf. P. lachrymans \\
\hline & & & Hemisbos cf. H. acuticornis \\
\hline & & & Bovinae gen. indet. \\
\hline & & Cervidae & Cervus sp. \\
\hline & & Giraffidae & Giraffa punjabiensis \\
\hline & & Hippopotamidae & Hexaprotodon sivalensis \\
\hline & & Suidae & Conohyus sindiensis \\
\hline & Perissodactyla & Equidae & Equus sp. \\
\hline & \multirow{4}{*}{ Proboscidea } & Elephantidae & Elephas planifrons \\
\hline & & Gomphotheriidae & Gomphotherium sp. \\
\hline & & \multirow{2}{*}{ Stegodontinae } & Stegodon insignis \\
\hline & & & Stegodon bombifrons \\
\hline
\end{tabular}

\section{The Lesser Himalaya}

The Lesser Himalaya is mainly composed of Precambrian to Lower Palaeozoic metamorphic rocks. These rocks are unfossiliferous except for few colonial blue-green algae known as Stro- 
matolites. Late Palaeozoic to Mesozoic rocks distributed in several intracratonic basins within the Lesser Himalayan rocks are known as the Gondwana sediments. The Gondwana sequence is a largely continental deposit, with some periodic marine incursions. The lithological succession and fossil content of Gondwana sequences in the Tansen area have been very well studied by Sakai (1983). The Tansen Group consists of the Sisne Formation (Permo-Carboniferous), Taltung and Amile Formations (Early Cretaceous-Paleocene), Bhaiskati Formation (Eocene) and Dumri Formation (Oligocene). Sah and Schleich (1990) reported an isolated Crocodylus tooth from the Bhaiskati Formation (Eocene), in the Tansen area, west Nepal. This is the only vertebrate fauna documented from the Lesser Himalayan rocks so far. With this evidence the vertebrate record in the Nepal Himalaya could reach back to Eocene.

\section{The Higher and the Tethys Himalaya}

The Higher Himalayan rocks composed of high-grade metamorphic gneiss, schists, marble and quartzite while the Tethys Himalayas are thick successions of fossiliferous rocks deposited during Palaeozoic and Mesozoic Eras. The fossiliferous rocks of Tethys Himalaya mainly contain marine invertebrates such as Foraminifera, Corals, Brachiopods, Bivalves, Ammonites and Conodonts. However, the remains from marine vertebrates are still unknown. The most famous invertebrare fossil is Ammonite (Saligrams), because of its relation with Hindu mythology.

\section{Vertebrate remains from the Pliocene-Pleistocene sediments in the Kathmandu Valley}

The Kathmandu Valley located at an altitude of ca. $1200 \mathrm{~m}$ is one of the large intermontane oval shaped basins within the Lesser Himalayan range in Nepal and stretches about $30 \mathrm{~km}$ in the east-west direction and $25 \mathrm{~km}$ in the north-south direction. The basin is enclosed by mountain ranges such as Shivapuri towards the north, Nagarjun towards the north-west, and Phulchoki towards the south. The basin fill sediments are fluvio-lacustrine or fluvial to fluviodeltaic in origin and are considered to have resulted from damming in the southern part of the valley (Sakai et al.2006). The valley sediments have been divided into different stratigraphic units by different researchers on the basis of lithology, facies analysis, radiocarbon dating and palaeomagnetic polarity data (Yoshida and Igarashi 1984, Yoshida and Gautam 1988, Sakai et al. 2001, Goddu et al. 2007 and Sakai et al. 2008). The oldest deposit is the Lukundol Formation (Late Pliocene to Early Pleistocene) which is distributed at the southern part of the basin and overlain by Chapagaon, Boregaon and Pyangaon terrace deposits formed during tilting of the lake towards north due to activation of Main Central Thrust (MCT) in south. The younger Kathmandu Lake covered the large area of the valley and the younger sediments like Kalimati, Dharmasthali, Gokarna, Tokha, Thimi and Patan Formations (Late Pleistocene) were subsequently deposited (Yoshida and Igarashi 1984, Dongol 1985, Yoshida and Gautam 1988, Sakai et al. 2001, Sakai et al. 2008).

The Lukundol Formation yielded many vertebrate fossil remains. A mandible of Stegodon ganesa was first reported from the Nakhu Khola area (Sharma 1973). West and Munthe (1981) found several fossils from the Lukundol Formation and correlated their findings with the Karewa Formation of Kashmir. On the basis of their discoveries they estimated the age of the fossiliferous horizons as Early Pleistocene. Corvinus and Sharma (1984) reported a partial lower molar dentition of a bovid from the Bhadrabas area in the northern part of the Kathmandu 
Valley. The extensive works carried out by West and Munthe (1981), Dongol (1985), West et al. (1988) and Sah et al. (1995-96) were from Chapagaon, Lukundol, Pharsidol and Khahare Khola areas in the southern part of the Kathmandu Valley. Paudayal et al. (2011) reported a bovid tooth from a surface exposure in Phaidhoka, east of the Bhaktapur on the way to Nala. Recently, Paudayal has collected six molars (possibly Bovidae) from the same area are under identification. The fossil vertebrate fauna investigated by different authors in the Kathmandu Valley sediments are summarized in table 3.
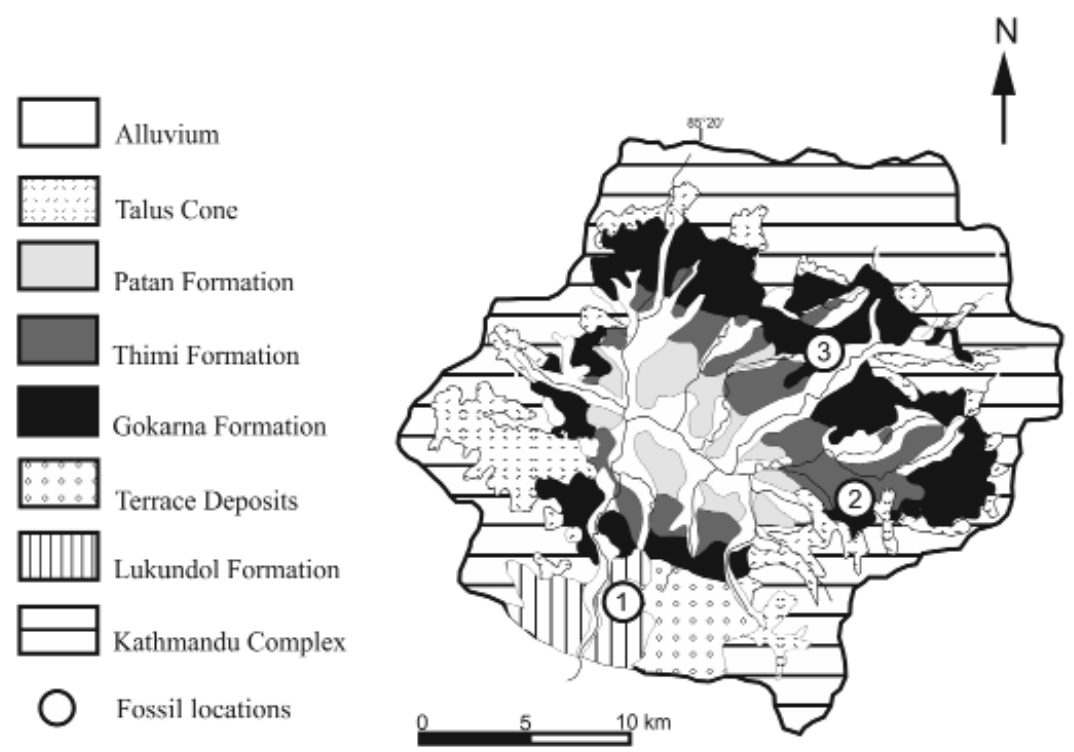

Figure 3.Vertebrate fossil localities in the Kathmandu Valley (1. Lukundol, 2. Phaidhoka, 3. Bhadrabas).

Plenty of elephant molars belonging to genera Stegodon and Elephas suggest that they were living in the natural forest in the southern part of the Kathmandu Valley. Today, the elephants are not found in the natural forest of Kathmandu. Elephants prefer tropical to subtropical warm climate. This evidence suggests that the climate in Late Pliocene to Lower Pleistocene in Kathmandu Valley was much warmer than that of today.

Table 3. Vertebrate fossils from the Kathmandu Valley sediments.

\begin{tabular}{|l|l|l|l|l|}
\hline CLASS & ORDER & FAMILY & $\begin{array}{l}\text { GENERA/ } \\
\text { SPECIES }\end{array}$ & PUBLICATIONS \\
\hline \multirow{2}{*}{ OSTEICHTHYS } & Cypriniformes & Cyprinidae & $\begin{array}{l}\text { Cyprinid cf. } \\
\text { Tor tor }\end{array}$ & West et al. (1988) \\
\cline { 4 - 5 } & & $\begin{array}{l}\text { Teleost } \\
\text { (indet.) }\end{array}$ & West et al. (1988) \\
\hline
\end{tabular}




\begin{tabular}{|c|c|c|c|c|}
\hline REPTILIA & Crocodilia & Crocodylidae & $\begin{array}{l}\text { Crocodylus } \\
\text { sp. }\end{array}$ & $\begin{array}{l}\text { West and Munthe } \\
\text { (1981) }\end{array}$ \\
\hline \multirow{15}{*}{ MAMMALIA } & \multirow{9}{*}{ Artiodactyla } & $\begin{array}{l}\text { Anthracotheri- } \\
\text { idae }\end{array}$ & gen. indet. & Dongol (1985) \\
\hline & & \multirow{4}{*}{ Bovidae } & $\begin{array}{l}\text { Bos nama- } \\
\text { dicus }\end{array}$ & $\begin{array}{l}\text { Corvinus and } \\
\text { Sharma (1984) }\end{array}$ \\
\hline & & & $\begin{array}{l}\text { Bos or Buba- } \\
\text { lus sp. }\end{array}$ & Dongol (1985) \\
\hline & & & gen. indet. & Paudayal et al. (2011) \\
\hline & & & gen. indet. & Sah et al. (1995-96) \\
\hline & & Suidae & $\begin{array}{l}\text { Potamo- } \\
\text { choerus } \\
\text { palaeindicus }\end{array}$ & Dongol (1985) \\
\hline & & $\begin{array}{l}\text { Hippopotami- } \\
\text { dae }\end{array}$ & $\begin{array}{l}\text { Hexa- } \\
\text { protodon } \\
\text { sivalensis }\end{array}$ & $\begin{array}{l}\text { West and Munthe } \\
\text { (1981) }\end{array}$ \\
\hline & & \multirow{2}{*}{ Cervidae } & gen. indet. & Dongol (1985) \\
\hline & & & Cervus sp. & Sah et al. (1995) \\
\hline & \multirow{6}{*}{ Proboscidea } & \multirow{6}{*}{ Elephantidae } & $\begin{array}{l}\text { Archidis- } \\
\text { kodon } \\
\text { planifrons }\end{array}$ & $\begin{array}{l}\text { West and Munthe } \\
\text { (1981) }\end{array}$ \\
\hline & & & $\begin{array}{l}\text { Elephas cf. } \\
\text { hysudricus }\end{array}$ & Dongol (1985) \\
\hline & & & $\begin{array}{l}\text { Elephas cf. } \\
\text { planifrons }\end{array}$ & Dongol (1985) \\
\hline & & & $\begin{array}{l}\text { Elephas } \\
\text { namadicus? }\end{array}$ & Sah et al. (1995-96) \\
\hline & & & $\begin{array}{l}\text { Stegodon } \\
\text { ganesha }\end{array}$ & $\begin{array}{l}\text { West and Munthe } \\
\text { (1981) }\end{array}$ \\
\hline & & & $\begin{array}{l}\text { Stegodon } \\
\text { sp. }\end{array}$ & Sharma (1973) \\
\hline
\end{tabular}

The vertebrate fossil record in Nepal goes back to Eocene. The Palaeozoic and Mesozoic rocks from the Tethys sediments contain plenty of invertebrates but the vertebrate remains are completely missing. The Miocene, Pliocene and Pleistocene vertebrate remains recovered from the Siwalik and Indo-Gangetic Plain are useful to trace out the evolution of animals and palaeo-environment after the collision of the Indian and Eurasian Plates. The upliftment 
process created new ecological niches for the animals in which they have to be adapted. The Plio-Pleistocene lacustrine sediments in the Kathmandu Basin yielded vertebrate fossils equivalent to the upper Siwalik. Investigation in this direction is still going on in the different part of the country. The new findings will certainly shed more light on the evolution of vertebrate fauna as well as climate history of the Nepal Himalaya.

\section{ACKNOWLEDGEMENTS}

The author would like to thank Dr. Ishan Gautam and Dr. Sudarshan Bhandari for providing valuable comments to improve the manuscript. The author would also like to thank two anonymous reviewers for their comments and suggestions.

\section{REFERENCES}

Appel, E., W. Roesler and G. Corvinus, 1991. Magnetostratigraphy of the Miocene Pleistocene Surai Khola Siwaliks in west Nepal. Geophys. Jour. Int., 105:191-198.

Appel, E. and W. Roesler, 1994. Magnetic polarity stratigraphy of the Neogene Surai Khola section, SW Nepal.Himal.Geol., 15:63-68.

Corvinus, G. and J. L. Sharma, 1984. A vertebrate fossil find in the Kathmandu Valley. Ancient Nepal, 82:27-32.

Corvinus, G., 1985. First prehistoric remains in the Siwalik Hills of Western Nepal. Quartaer, 35-36:65-182.

Corvinus, G., 1987. Patu, a new Stone Age site of a jungle habitat in Nepal. Quartaer, 37-38: 135-187.

Corvinus, G., 1988a. The Mio-Plio-Pleistocene litho-and biostratigraphy of the Surai Khola Siwaliks in west Nepal: first results. C. R. Acad. Sci. Paris, 306 (11):1471-1477.

Corvinus, G., 1988b. Plio-Pleistocene fauna and flora from the Siwalik Group of sediments in Nepal and their environmental implication. In Whyte, P. et al. (eds) The Palaeo- environment of East Asia From Mid-Tertiary I. Centre for Asian Studies. University of Hongkong.

Corvinus, G., 1989. The Patu industry in its environment in the Siwaliks in eastern Nepal. Quartaer, 39-40:95-123.

Corvinus, G., 1990. Litho and biostratigraphy of Siwalik succession in Surai Khola area, Nepal. The Palaeobotanist, 38:293-297.

Corvinus, G., 1993. The Siwalik Group of sediments at Surai Khola in western Nepal and its palaeontological record. Jour. Nepal Geol. Soc., 9:21-35.

Corvinus, G., 1994. The Surai Khola and Rato Khola fossiliferous sequence in the Siwalik Group, Nepal. Himal. Geol., 15:49-61.

Corvinus, G. and A. C. Nanda, 1994. Stratigraphy and palaeontology of the Siwalik Group of Surai Khola and Rato Khola in Nepal. Neues Jahrbuch für Geologie und Paläontologie,191 (1):25-68.

Corvinus, G., 1995. The Satpati handaxe site and the Chabeni uniface site in southern Nepal. 
Quartaer, 45-46:15-36.

Corvinus, G., 1996. The prehistory of Nepal after ten years of research. Indo-Pacific Prehistory Association Bulletin, 14(1) (Chiang Mai Papers):43-56.

Corvinus, G. and L. N. Rimal, 2001. Biostratigraphy and geology of the Neogene Siwalik group of the Surai Khola and Rato Khola areas in Nepal. Palaeogeography, Palaeoclimatology and Palaeoecology, 165 (3-4):251-279.

Dongol, G. M. S., 1985. Geology of the Kathmandu fluviatile lacustrine sediments in the light of new vertebrate fossil occurrences. Jour. Nepal Geol. Soc., 3(1):43-57.

Goddu, S. R., E. Appel, P. Gautam, E. A. Oches and F. Wehland, 2007. The lacustrine section at Lukundol, Kathmandu Basin, Nepal: dating and magnetic fabric aspects. Jour. Asian Earth Sci., 30(1):73-81.

Kotlia, B. S. and P. D. Mathur, 1997. Lower vertebrate fauna from the Upper Siwaliks of Surai Khola, Dang Valley, Western Nepal. Jour. Paleo. Soc. India, 42:169-174.

Munthe, J., B. Dongol, J. H. Hutchison, W. F. Kean, K. Munthe and R. M. West, 1983. New fossil discovery from Miocene of Nepal include a hominoid. Nature, 303(5915):331-333.

Nanda, A.C. and G. Corvinus, 1993. A report on the occurrence of the Tatrot and Pinjor faunas from the Siwalik Group of Nepal. Jour. Him. Geol., 3(2):209-211.

Nanda, A.C. and G. Corvinus, 2000. Skull characteristics of two proboscideans from the Upper Siwalik Subgroup of Nepal. Neues Jahrbuch für Geologie und Paläontologie, 217(1):89-10.

Paudayal, K. N., S. Panthee and C. Hertler, 2011. A bovid specimen from Late Pleistocene deposits in the Kathmandu Basin, Nepal. Jour. Strat. Asso. Nepal, 7:9-14.

Sakai, H., 1983.Geology of the Tansen Group of the Lesser Himalaya in Nepal. Memoirs of the Faculty Science, Kyushu University, Series D, XXV(1):27-74.

Sah, R. B., P. D. Ulak, A. P. Gajurel and L. N. Rimal, 1994. Lithostratigraphy of Siwalik sediments of Amlekhganj-Hetauda area, Sub-Himalaya of Nepal. Himal. Geol.,15:37-48.

Sah, R. B. and H. H. Schleich, 1990. An Eocene crocodile record from Bhainskati Khola (Dumri Area), South Nepal. Mitteilungen der Bayerischen Staatssammlung für Paläontologie und Historische Geologie, München, 30:51-56.

Sah, R.B., M. Paudel and D.Ghimire,1995-96. Lithological successions and some vertebrate fossils from the fluviolacustrine sediments of the Kathmandu Valley, Central Nepal. Nahson Bulletin, 5-6:21-27.

Sakai, H., R. Fuji, Y. Kuwahara, B. N. Upreti and S. D. Shrestha, 2001. Core drilling of the basin fill sediments in the Kathmandu Valley for paleoclimatic study: preliminary results. Jour. Nepal Geol. Soc., 25 (Sp. Issue):9-18.

Sakai, H., W.Yahagi, R. Fujii, T. Hayashi and B. N. Upreti, 2006. Pleistoceneuplift of the Himalayan frontal ranges recorded in the Kathmandu and Siwalik basins. Palaeogeography, Palaeoclimatology, Palaeoecology, 241:16-27. 
Sakai, T., A. P. Gajurel, H. Tabata, N. Ooi, T.Takagawa, H.Kitagawa and B. N. Upreti, 2008. Revised lithostratigraphy of fluvio-lacustrine sediments comprising northern Kathmandu basin in central Nepal. Jour. Nepal Geol. Soc., 37:25-44.

Sharma, C. K., 1973. Geology of Nepal. Man Ram Sharma, Kathmandu, Nepal.

West, R. M., J. Munthe Jr., J. R. Lukacs and T. B. Shrestha, 1975, Fossil mollusca from the Siwaliks of eastern Nepal. Current Science, 44(10):497-498.

West, R. M., J. R. Lukacs, J. R.Munthe Jr. and S. T. Hussain, 1978. Vertebrate fauna from Neogene Siwalik Group, Dang Valley, western Nepal. Jour. Palaeo., 54(5):1015-1022.

West, R.M. and J. Munthe, 1981.Neogene vertebrate Palaeontology and Stratigraphy of Nepal Jour. Nepal Geol. Soc., 1:1-14.

West, R. M., 1984. Siwalik faunas from Nepal: palaeoecologic and palaeoclimatic implications. In Whyte, R. O. (ed) The evolution of the east Asian environment, v. II, Palaeobotany, Palaeozoology and Palaeoanthropology. Centre of Asian Studies, University of Hongkong, pp 724-44.

West, R. M. and J. Munthe, 1983. Cenozoic vertebrate palaeontology and stratigraphy of Nepal. Jour. Nepal. Geol. Soc., 1:1-14.

West, R. M., T. R. Pant, J. H. Hutchison and G. C. Conroy, 1983. Fossil mammal footprints from the Siwaliks of south central Nepal. Current Science, 51(1):12-16.

West, R.M., G.M.S. Dongol, J. Munthe, J.H. Hutchinson and V.J. Gupta, 1988. The Palaeoenvironment of East Asia from the Mid-Tertiary. In Whyte, P. (ed) Late Neogene and Quaternary Geology, Palaeontology and Palaeoenvironment of the Kathmandu Valley, Central Nepal and the Churia Hills, western Nepal. Proceedings of the Second Conference, pp 916-936.

West, R. M., J. H. Hutchison and J. Munthe, 1991. Miocene vertebrates from the Siwalik Group, western Nepal. Jour. Vert. Palaeo., 11(1):108-129.

West, R. M., 1996. The Cenozoic of Nepal: mountain elevation and vertebrate evolution. Jour. Nepal Geol. Soc., 14:11-19.

Yoshida, M. and P. Gautam, 1988. Magnetostratigraphy of Pliocene-Pleistocene lacustrine deposits in the Kathmandu Valley, central Nepal. Proceedings of Indian Natural Science Academy, 54A(30):410-417.

Yoshida, M. and Y. Igarashi, 1984. Neogene to Quaternary Lacustrine sediments in the Kathmandu Valley, Nepal. Jour. Nepal Geol. Soc., 4:73-100.

\section{AUTHOR'S ADDRESS}

Khum Narayan Paudayal

Central Department of Geology

Tribhuvan University, Kirtipur, Kathmandu, Nepal

(email: khum99@gmail.com) 